\title{
Regional mechanisms and intra-state conflicts: Implementing the African Union's principle of non-indifference?
}

Migai Akech *

\section{Introduction}

The member states of the Organisation of African Unity (OAU) established the African Union (AU) in 2001, following recognition that Africa needed a more effective institution that could maintain peace and security. In particular, the 1994 genocide in Rwanda demonstrated to the continent that it needed to enhance its ability to act before conflicts became unmanageable and destructive. ${ }^{1}$ The AU consequently established an institutional framework for the prevention, management, and resolution of conflicts. This institutional framework consists of two parallel frameworks, namely the African Peace and Security Architecture (APSA) ${ }^{2}$ and the African Governance Architecture (AGA) ${ }^{3}$. These two frameworks should be examined together given that bad governance is often responsible for many conflicts in Africa. Accordingly, establishing and sustaining good governance constitutes an effective strategy for preventing these conflicts.

At the same time, Africa has a long history of regional integration. The continent houses various regional economic communities (RECs) and regional mechanisms (RMs), some of which predate the OAU. Although the majority of these initiatives were formed primarily to further economic cooperation, they now embrace the promotion of democracy and good governance as well as peace and security in their agenda. It is believed that, compared to the AU, these initiatives have certain comparative advantages, including a better understanding

\footnotetext{
See generally Taylor C, 'The cultural face of terror in the Rwandan genocide of 1994' in Leban A, Annibilating difference: The anthropology of genocide, University of California Press, California, 2002.

African Union Peace and Security, -< https://www.peaceau.org/en/> on 17 February 2020.

African Governance Architecture, -< http://aga-platform.org/> on 17 February 2020.
}

* Associate Professor, University of Nairobi, School of Law. 
of the socio-cultural and political nuances in their respective regions'. ${ }^{4}$ The AU therefore recognises that the RECs and RMs play a significant role in maintaining peace and security on the continent. This explains the Protocol Relating to the Establishment of the Peace and Security Council of the African Union ${ }^{5}$ on how it should work with the RECs and RMs, and the Memorandum of Understanding on cooperation in the area of peace and security between the AU and the RECs and RMs of Northern and Eastern Africa regional bodies signed in 2008 (MoU of 2008). In practice, however, this partnership has been characterised by challenges such as lack of clarity over roles and responsibilities, making it ineffective. The partnership should therefore be reviewed. The on-going reform process led by President Kagame that seeks to establish 'a system of governance capable of addressing the challenges facing the Union' provides a much-needed platform for this review. ${ }^{6}$

This paper evaluates the role of RMs in managing intra-state conflicts under the AU's normative order, consisting of a two-pronged institutional framework. It argues that the AU member states remain deeply attached to the old-order principles of sovereignty and non-interference, and are consequently exceedingly reluctant to embrace and implement the new-order principle of nonindifference. Further, little effort has been put towards implementing regional norms on democracy, governance and human rights. As a result, the $\mathrm{AU}$ and the RMs do not speak with one voice. In particular, they have not properly addressed the increasingly common case of conflicts caused by incumbent regimes retaining power by manipulating the law, the electoral process, or the judicial process. The recent experiences of Burundi and Uganda illustrate this challenge. In Burundi, the Government instigated a referendum in May 2018 that culminated in an amendment of the Constitution that increased the presidential term from five to seven years. ${ }^{7}$ Further, this amendment allowed the incumbent President, who has been in office since 2005, to stand for reelection, despite having already served three terms. Likewise, Uganda's Parliament changed the Constitution in

\footnotetext{
Lucey A and Moyosere A, 'Sustainable peace: Driving the African Peace and Security Architecture through ECOWAS', ISS Paper 301, Institute for Security Studies, 2016.

Protocol relating to the establishment of the peace and security council of the African Union, 9 July 2002.

Decision on the institutional reform of the African Union, 29 January 2017, Assembly/AU/Dec.606 (XXVII).

See 'Burundi approves referendum extending Nkurunziza's rule until 2034', News Pulse Online, 21 May $2018-</ /$ www.newspulseonline.com/burundi-approves-referendum-extending-nkurunzizasrule-until-2034/> on 20 February 2020.
} 
December 2017 to remove the age limit of seventy-five years for presidential candidates, thereby allowing the incumbent President to run for a sixth term in office. ${ }^{8}$

Part II of the paper establishes an analytical framework. Part III examines the role of the RMs in managing intra-state conflicts. Part IV is a brief conclusion, while Part V makes a number of recommendations.

\section{Governing peace and security in Africa}

Confronted with violent conflicts within its member states, the OAU invariably declined to intervene, on the rationale that doing so would violate the organisation's principles of sovereignty and non-interference in the internal affairs of those states. ${ }^{9}$ In light of these principles, the OAU member states focused on anticipating and preventing conflicts, meaning that the organisation refrained from peacekeeping activities, which they thought was the primary responsibility of the United Nations (UN). ${ }^{10}$ The hope was 'that a preventive diplomacy would dramatically reduce the need for subsequent peacekeeping'. ${ }^{11}$ The Mechanism for Conflict Prevention, Management and Resolution established in 1993 (OAU Mechanism) constituted the instrument for realising this strategy. ${ }^{12}$ However, the Burundi/Rwanda genocide of 1993-4 marked a turning point, the members agreeing at the 1995 summit in Addis Ababa that the organisation now needed to be involved in peacekeeping. At the same time, the RECs often stepped in to fill the vacuum left by the OAU, albeit in an ad hoc manner. ${ }^{13}$ For example, the Economic Community of West Africa (ECOWAS) responded to conflicts in Guinea-Bissau, Liberia, and Sierra Leone; as did the Southern African Develop-

$8 \quad$ See 'Uganda enacts law ending presidential age limits', Aljazeera, 2 January $2018-<$ https://www. aljazeera.com/news/2018/01/uganda-enacts-law-presidential-age-limits-180102182656189.html > on 20 February 2020.

9 Desmidt $\mathrm{S}$ and Hauck V, 'Conflict management under the African peace and security architecture (APSA): Analysis of conflict prevention and conflict resolution interventions by the African Union and regional economic communities in violent conflicts in Africa for the years 2013-2015', European Centre for Development Policy Management, Discussion Paper No 211, April 2017.

10 Williams P, 'The peace and security council of the African Union: Evaluating an embryonic international institution' 47(4) Journal of Modern African Studies, 2009, 604.

11 Williams P, 'The peace and security council of the African Union: Evaluating an embryonic international institution', 605.

12 See Muyangwa $\mathrm{M}$ and Hayatou $\mathrm{A}$, An assessment of the $\mathrm{OAU}$ mechanism for conflict prevention, management and resolution, 1993-2000, International Peace Academy, New York, 2000.

13 Williams P, 'The peace and security council of the African Union', 605. 
ment Community (SADC) in relation to conflicts in Lesotho and the Democratic Republic of the Congo. ${ }^{14}$

Following the establishment of the AU, the member states decided to review the OAU Mechanism, a process that culminated in the adoption of the Protocol Relating to the Establishment of the Peace and Security Council of the African Union (PSC Protocol) in Durban on 9 July 2002. The PSC Protocol established the following institutions that now constitute the APSA: the PSC as the standing decision-making organ; the African Union Commission (AUC) to implement decisions of the PSC and give it operational support; the African Standby Force (ASF) consisting of five regional brigades and responsible for peace support operations; the Panel of the Wise (PoW) consisting of five prominent African personalities and responsible for preventive diplomacy, among other things; the Peace Fund to finance the operations of APSA; and the Continental Early Warning System (CEWS) to provide timely and reliable data and policy response options on potential conflicts. APSA's mandate is to prevent, manage and resolve conflicts in Africa. The RECs and RMs have established similar structures, which form part of the APSA. In this respect, Article 16 of the PSC Protocol provides that RECs and RMs are part of the AU's security architecture. Further, the AU and the RMs signed a memorandum of understanding in 2008 on cooperation in the area of peace and security. ${ }^{15}$ Thus, it is expected that the AU institutions and the RECs and RMs will work together and coordinate their peace and security initiatives.

The APSA operates in a different normative context, compared to the OAU Mechanism. The preamble to the AU's Constitutive Act recognises that the 'scourge of conflicts in Africa' is a major impediment to development, and that peace, security and stability are a prerequisite for the realisation of development. Further, it underscores the determination of the members to 'promote and protect human and peoples' rights, consolidate democratic institutions and culture, and... ensure good governance and the rule of law'. Three objectives are critical to realising this mission: (1) promoting peace, security and stability; (2) promoting democracy and good governance; and (3) promoting human and people's rights. ${ }^{16}$ Whereas the AU continues to respect the principles of sover-

14 Williams P, ‘The peace and security council of the African union', 605.

15 African Union, 'Memorandum of understanding on cooperation in the area of peace and security between the African Union, the regional economic communities and the coordinating mechanisms of the regional standby brigades of Eastern Africa and Northern Africa', Addis Ababa, 2008 (this memorandum is hereinafter referred to as AU-RECs MoU).

16 Article 3, Constitutive Act of African Union (2000). 
eignty and non-interference by a member state in the internal affairs of another, it now also recognises the principle of non-indifference, which it defines as 'the right of the Union to intervene in a member state pursuant to a decision of the Assembly in respect of grave circumstances, namely: war crimes, genocide and crimes against humanity as well as a serious threat to legitimate order to restore peace and stability .... ${ }^{17}$ Another key principle is the condemnation and rejection of 'unconstitutional changes of government'.

Conversely, the 2007 AGA, which entered into force in 2012, is a more recent development. ${ }^{19}$ It is a platform that seeks to enhance the ratification, domestication and implementation of AU norms on governance, including norms on democracy, good governance, popular participation, protecting and promoting human and peoples' rights, and promoting peace, security and stability. In particular, AGA seeks to enhance the ratification, domestication and implementation of the African Charter on Democracy, Elections and Governance (ACDEG).$^{20}$ Further, it is envisaged that the AGA will achieve its objectives by enhancing coordinated actions among its members, and developing appropriate capacity and responses to governance challenges. ${ }^{21}$ While member states retain primary responsibility in the governance realm, the AGA seeks to complement this responsibility by ensuring greater coordination at both regional and continental levels. ${ }^{22}$ The AGA thus seeks to help AU member states to overcome the challenges they face in implementing these norms, including the lack of coherence, coordination and synergy among AU organs and the RECs. ${ }^{23}$ Above all, AGA's goal is to support the APSA to 'address structural root causes and drivers of conflicts.'. ${ }^{24}$

How has this two-pronged institutional framework handled emergent conflicts in the new normative context? In particular, how have the two critical principles - of non-indifference, and the condemnation and rejection of unconsti-

\footnotetext{
Article 4(h), Constitutive Act of African Union (2000, as amended 2003).

8 Article 4(p), Constitutive Act of African Union (2000).

19 See AU, Declaration on the theme of the summit: Towards greater unity and integration through shared values', Assembly/AU/Decl.1 (XVI), 30-31 January 2011.

20 African Governance Architecture, - < http://aga-platform.org/> 17 February 2020.

21 African Union, Framework of the African Governance Arcbitecture (2007) at 2

22 African Union, Framework of the African Governance Architecture (2007) at 3.

23 Wachira G, 'Strengthening the peace and governance nexus within the African Union: Enhancing synergy between the African Governance Architecture (AGA) and the African Peace and Security Architecture (APSA)', Norwegian Institute of International Affairs (NUPI), Report No 7, 2017.

24 Wachira G, 'Strengthening the peace and governance nexus within the African union: Enhancing synergy between the African governance architecture (AGA) and the African peace and security architecture (APSA)', 10.
} 
tutional changes of government - been articulated in practice? The following section seeks to answer these questions, focusing on the role of the RECs and RMs and their relationship with the AU organs in managing intra-state conflicts.

\section{The role of the regional mechanisms in managing conflicts in the new normative context}

At the international level, the UN Charter gives regional organisations the authority to respond to situations that threaten international peace and security, albeit with the authorisation of the UN Security Council. ${ }^{25}$ Such responses could consist of any of the following: diplomatic interventions, mediation efforts and preventive diplomacy, peace support operations or post-conflict reconstruction and development. ${ }^{26}$ The AU's Executive Council has taken the view that regional organisations that are proximate to conflicts should be empowered to act, since the UN General Assembly and Security Council are often far from the scenes of conflicts and may not appreciate the nature and development of conflict situations. ${ }^{27}$ The $\mathrm{AU}$ is therefore prepared to act and seek subsequent approval, particularly in times of urgency. ${ }^{28}$ In principle, the AU can intervene or authorise an $\mathrm{RM}$ to intervene on the basis that grave circumstances (war crimes, genocide or crimes against humanity) exist, or there is a serious threat to legitimate order. By this right to intervene, the AU Constitutive Act signifies a departure from the past, stating that the AU will not be indifferent to the occurrence of such grave circumstances in its member states. The right to intervene should therefore be seen in the context of the international community's commitment to the 'responsibility to protect' (R2P) principle; that it will take collective action where a state fails to protect its population or a section thereof from genocide, war crimes, ethnic cleansing and crimes against humanity. ${ }^{29}$

Article 53, Charter of the United Nations and statute of the International Court of Justice, 26 June 1945.

Desmidt $\mathrm{S}$ and Hauck V, 'Conflict management under the APSA', 8.

African Union, 'The common African position on the proposed reform of the UN', The Ezulwini Consensus, seventh extraordinary session of the AU Executive Council, Addis Ababa, 7-8 March 2005.

28 Sarkin J, 'The role of the United Nations, the African Union and Africa's sub-regional organisations in dealing with human rights problems: Connecting humanitarian intervention and the responsibility to protect' 53(1) Journal of African Law, 2009, 7.

29 UNGA, '2005 World Summit Outcome', Resolution 60/1, UN Doc A/RES/60/1 (24 October 2005). 
However, the RMs sometimes act without the approval of the AU, particularly where there is no agreement on the actions to be taken. Indeed, some of the instruments establishing the RMs, which all predate the AU Constitutive Act, give them broader bases for intervening in member states. For example, the Economic Community of West African States (ECOWAS) is empowered to intervene: (1) when internal conflict threatens 'to trigger a humanitarian disaster' or 'poses a serious threat to peace and security in the sub-region'; or (2) where there are 'serious and massive violations of human rights and the rule of law'; or (3) where there is 'an overthrow or attempted overthrow of a democratically elected government; or (4) in any other situation where the Mediation and Security Council deems intervention to be necessary. ${ }^{30}$ Similarly, the Southern African Development Community (SADC) is empowered to intervene where significant intra-state conflict exists, for example: (1) where there is large-scale violence between sections of the population or between a state and sections of the population, including genocide, ethnic cleansing and gross violation of human rights; or (2) where there has been a coup or other threat to the legitimate authority of a state; or (3) where a condition of civil war or insurgency exists; or (4) there is a conflict that threatens peace and security in the region or in the territory of another state party.31 Nevertheless, there is an informal understanding that the RMs will seek AU authorisation for their interventions. ${ }^{32}$ However, it is difficult to see how the AU and the RMs will agree on this issue given that the rulebooks of the latter grant them broader latitudes for intervention.

The partnership between the AU and the RMs is therefore characterised by pragmatism. This explains why the PSC Protocol provides that the modalities of this partnership 'shall be defined by the comparative advantage of each and the prevailing circumstances' ${ }^{33}$ Further, the PSC Protocol requires the chairperson of the AU Commission to involve the RMs in the establishment and functioning of the CEWS and ASF, ${ }^{34}$ and strengthen coordination by establishing liaison offices to the RMs, and encouraging these sub-regional mechanisms to

30 Article 25, Protocol relating to the mechanism for conflict prevention, management, resolution, peacekeeping and security, 10 December 1999.

31 Article 11(2), Protocol on politics, defence and security cooperation, 14 August 2001.

32 African Union, 'Roadmap for the Operationalization of the African Standby Force: Experts' meeting on the relationship between the AU and the Regional Mechanisms for Conflict Prevention, Management and Resolution' 22-23 March 2005, EXP/AU-RECS/ASF/4 (I).

33 Article 16(1)(b), Protocol relating to the establishment of the peace and security council of the African Union, 9 July 2002.

34 Article 16(6), Protocol relating to the establishment of the peace and security council of the African Union. 
establish liaison offices to the AU Commission..$^{35}$ In practice, pragmatism has meant that the AU sometimes defers to the efforts of the RMs, and sometimes takes the lead, depending on the circumstances of each case. ${ }^{36}$

The MoU of 2008 - which governs cooperation between the AU, the RECs and the RMs in all areas relevant for the promotion and maintenance of peace, security and stability ${ }^{37}$ - reinforces the PSC Protocol. It establishes two key principles, namely (1) recognition and respect for the primary responsibility of the AU in the maintenance and promotion of peace, security and stability in Africa; and (2) that the principles of subsidiarity, complementarity and comparative advantage shall guide the partnership. ${ }^{38}$

The RMs have played a critical role in maintaining and promoting peace, security and stability in their regions. ECOWAS has been exemplary in this respect, in terms of identifying emerging threats to peace and security, and dealing with conflict. ${ }^{39}$ For example, it played a central role in Guinea's return to democratic rule in February 2010 following a military coup d'etat in December 2008. It was also instrumental in resolving the conflict in Mali in July 2012, after the PSC had delegated this task to it. ${ }^{40}$

Despite such successes, the AU has struggled to implement the principles of non-indifference and rejection of unconstitutional changes of government in significant respects. Thus, commentators assert that the AU's 'norms, values and principles have been unevenly applied to states that have fallen foul of them'. ${ }^{41}$ As the following cases demonstrate, the AU and the RMs have taken differing approaches and actions on these questions, which has hindered their ability to manage or resolve conflicts. Further, these approaches and actions have not been coordinated in a number of cases. ${ }^{42}$ This lack of coordination can in part be explained by the absence of a clear definition or shared understanding of the principle of subsidiarity, which the AU and the RMs consequently give varied or

\footnotetext{
35 Article 16(8), Protocol relating to the establishment of the peace and security council of the African Union.

36 See Murithi T, The African Union: Pan-Africanism, peacebuilding and development, Ashgate Publishing Company, London, 2005.

37 Section $\mathrm{V}, \mathrm{AU}$-RECs $M o U$.

38 Section IV, AU-RECs MoU.

39 Wachira G, 'Strengthening the peace and governance nexus within the African union', 23.

40 Vorrath J, Imbalances in the African Peace and Security Architecture: The current approach to capacity-building needs to be challenged, German Institute for International and Security Affairs, Berlin, Stiftung Wissenschaft und Politik (SWP) Comments 29, 2012.

${ }^{41}$ Aning K, The African Union's Peace and Security Architecture: Defining an emerging response mechanism, Nordic Africa Institute, Lecture Series on African Security, Uppsala, 2008, 3.

42 Wachira G, 'Strengthening the peace and governance nexus within the African Union', 37.
} 
opposing interpretations. ${ }^{43}$ It is, therefore, unhelpful that the MoU of 2008 does not specify how the principles of subsidiarity, complementarity and comparative advantage are to be implemented. For example, in some case the lack of clarity has created friction between the AU and the RMs in crisis situations. ${ }^{44}$

In addition, the RMs face considerable challenges that hinder their effectiveness. For example, a good number of these RMs have overlapping memberships and mandates. The fact that several states are members of different RECSs/RMs hinders coherence and coordination of approaches and responses. ${ }^{45}$ It also causes ambiguity and confusion over leadership and responsibilities. ${ }^{46}$ Further, while the AU has embraced the principle of non-indifference, the RMs continue to adhere to the principles of sovereignty and non-intervention, which considerably constrains the ability of the AU to intervene at an early stage. ${ }^{47}$ For example, a key principle of the Agreement Establishing the Intergovernmental Authority on Development (IGAD) is 'non-interference in the internal affairs of member states. ${ }^{38}$

Take the case of Burundi, where instability re-emerged following President Pierre Nkurunziza's declaration in April 2015 that he would seek a third term in office. This declaration sparked protests and an attempted coup, and created a humanitarian crisis characterised by the death and displacement of citizens. ${ }^{49}$ Nkurunziza subsequently won a highly controversial election, which was conducted in a climate of serious restrictions of basic liberties. ${ }^{50}$ At first, the AU adopted soft measures such as deploying diplomats, human rights observers and military observers that merely sought to contain the manifestations of the conflict while ignoring its underlying causes. ${ }^{51}$ The AU assigned responsibility to the East African Community (EAC), which appointed Uganda's President Yoweri Museveni as chief negotiator. However, the EAC-led dialogue did not make headway, Nkurunziza having refused to negotiate with the opposition.

43 Desmidt $\mathrm{S}$ and Hauck V, 'Conflict management under the APSA', 7.

44 Nathan L, African Peace and Security Architecture (APSA) 2014 assessment study: Final report, 16 April 2015.

45 Arthur P, 'Promoting security in Africa through regional economic communities (RECs) and the African Union's African Peace and Security Architecture (APSA)' 9(1) Insight on Africa, 2017,15.

46 Rein C, 'Enhancing peace and security in Africa through institutional cooperation' 36(2) Contemporary Security Policy, 2015, 269.

47 Rein C, 'Enhancing peace and security in Africa through institutional cooperation', 269.

48 Article 6A (b), Agreement Establishing the Intergovernmental Authority on Development, 1996.

49 International Crisis Group, The African Union and the Burundi Crisis: Ambition versus reality, Crisis Group Africa Briefing No 122, Brussels, 2016.

50 See International Refugee Rights Initiative (IRRI), Burundi: A Country on the edge, 2016.

51 Wachira G, 'Strengthening the peace and governance nexus within the African Union', 27. 
Concerned that the situation was rapidly deteriorating, the PSC issued a communiqué in December 2015, authorising a peace-support operation. In this communiqué, the PSC stated that if the regime was not willing to accept a 5000 AU force, the PSC would recommend to the AU Assembly to invoke article 4(h) of the AU Constitutive Act. However, Nkurunziza's government rejected the AU operation, stating that it would be an 'invasion and occupation force'. ${ }^{52}$ Unfortunately, a divided AU Assembly failed to invoke the principle of non-indifference. For some member states, sovereignty trumped human rights; for others, it was necessary to give mediation more time. ${ }^{53}$ The message to Nkurunziza was therefore that he could forge ahead with the plans to abolish presidential term limits provided he kept casualties to a minimum. ${ }^{54}$

The Burundi case illustrates why proximity, often claimed to be an advantage that the RMs enjoy over the AU, can serve to undermine the former's ability to manage conflicts in their regions. At the time, President Museveni, the chief negotiator, was seeking a fifth mandate, having amended presidential term limits in 2005. Angola's President Jose Eduardo dos Santos had ruled Angola since 1979. In the Democratic Republic of Congo (DRC), President Joseph Kabila was preparing to extend his stay in office. And while Rwanda's President Paul Kagame asked Nkurunziza to step down, Rwanda's Constitution had recently been amended to allow Kagame to stay in office until 2034 in principle. ${ }^{55}$ These domestic considerations hindered the authority and interest of these governments to intervene in Burundi.

Tensions between Rwanda and Tanzania over security issues in the DRC also made these countries reluctant partners. ${ }^{56}$ Further, mediators or facilitators are often accused of favoring sitting governments, even if their stated goal is to maintain short-term stability. In Burundi's case, for example, the EAC member states were not united on how to resolve the crisis: while Rwanda sought regime change, Uganda and Tanzania favored maintaining the status quo. ${ }^{57}$ Accordingly, while the principle of subsidiarity dictates that the RMs should be the first responders in the event of a conflict, the foregoing realities often require the AU to intervene as soon as possible.

\footnotetext{
52 International Crisis Group, The African Union and the Burundi Crisis.

53 International Crisis Group, The African Union and the Burundi Crisis.

54 International Crisis Group, The African Union and the Burundi Crisis.

55 International Crisis Group, The African Union and the Burundi Crisis.

56 Bouka Y, Missing the target: The African Union's mediating efforts in Burundi, Egmont Royal Institute for International Relations, Africa Policy Brief No 15, 2016.

57 Bouka Y, Missing the target: The African Union's mediating efforts in Burundi, 3.
} 
Confronted with conflicts generated by unconstitutional changes of government, the $\mathrm{AU}$ and the RMs have favored approaches that largely serve to maintain the status quo without addressing the root causes of the conflicts, such as the perceptions and realities of marginalisation of communities by government. Indeed, they have adopted a narrow definition of the term 'unconstitutional change of government'. ${ }^{58}$ Thus, they will seek to intervene where an incumbent refuses to relinquish power after a free and fair election, as they recently did in the Cote d'Ivoire and Gambia. However, they have been exceedingly reluctant to intervene where an incumbent manipulates the law, the electoral process, or the judicial process to retain power, as the recent cases of Burundi in 2015 and Kenya in 2017 demonstrate. The AU's approach, therefore, seems to be to wait until conflicts become full-blown crises characterised by catastrophic violence before intervening. In practice, the $\mathrm{AU}$ is often hesitant to intervene until the RMs do so. Unfortunately, the RMs often do not intervene in a timely manner, due to the domestic considerations of their members and regional power politics. ${ }^{59}$ And when they intervene, their efforts largely consist of soft diplomacy endeavors that the incumbent regimes rebuff, saying there is no crisis, but simultaneously declining or frustrating international observer missions sent to ascertain the situation on the ground. ${ }^{60}$

Clearly, a more proactive approach focusing on diffusing tensions by addressing the root causes of conflicts - such as bad governance - would facilitate the attainment of peace and security. The AU therefore needs to integrate the APSA and AGA frameworks, and make greater use of the latter as it is better tailored to addressing and redressing the root causes of Africa's conflicts. The ACDEG is instructive here, in that it embraces a broader definition of the term 'unconstitutional change of government' that includes 'accessing or maintaining power by illegal means'. ${ }^{61}$ The implication is that incumbents that retain power by illegal means - for example, fraudulent elections - should be treated similarly to those responsible for unconstitutional changes of government. ${ }^{62}$ Where the practice of electoral authoritarianism is the norm, as is arguably the case among the EAC member states, the RMs are rendered powerless to intervene in con-

\footnotetext{
58 International Crisis Group, The African Union and the Burundi Crisis.

59 International Crisis Group, The African Union and the Burundi Crisis, 11: Observing that in the Burundi case, '[d]istrust of Rwanda's perceived destabilisation of the region, and its alleged assistance to the armed insurrection, have shaped the response of other neighbours and contribute to EAC paralysis'.

60 IRRI, Burundi: A Country on the edge, 22.

${ }_{61}$ Article 23, African Charter on Democracy, Elections and Governance (2007).

62 Vandeginste S, 'The African Union, constitutionalism and power-sharing' 57(1) Journal of African Law, 2013, 23.
} 
flicts generated by such illegalities. Going forward, a need arises to harmonise the legal frameworks of the $\mathrm{AU}$ and the RMs, so that they can adopt common approaches to regional norms on democracy, governance and human rights.

Whenever they have intervened, the AU and the RMs have favored instruments such as power-sharing agreements, as the cases of Kenya and Zimbabwe in 2008 demonstrate. However, these agreements merely enable peace and security in the short-term and arguably compromise the longer-term goal of democratic state building, which establishing long-lasting peace and security requires. ${ }^{63}$ Arguably, the AU's policy of using power-sharing agreements cannot be reconciled with its claim of adherence to constitutionalism. ${ }^{64}$ Indeed, it is argued that ECOWAS has been more successful because it has stressed 'the central role of democratization and good governance in [its] programmes of conflict management and resolution'. ${ }^{65}$ And as the Revised Treaty of the Economic Community of West African States provides, 'democratization, coupled with responsive and responsible governance, is the most effective conflict management tool'. ${ }^{66}$ In contrast, there is no consensus among the IGAD member states on issues of governance. ${ }^{67}$

Despite the MoU of 2008, the actions of the AU and the RECs have either been uncoordinated or poorly coordinated in a number of cases. For example, this happened in Togo in 2005 when the AU and ECOWAS adopted contradictory approaches. Following the death of President Gnassingbe Eyadema, the military announced that his son, Fauré Gnassingbe, would become President, contrary to the Constitution. The AU and ECOWAS condemned this move, and prevailed on Fauré to commit to elections within 60 days and resign as interim President until these elections occurred. But once he resigned, ECOWAS removed its sanctions, whilst the PSC imposed its own sanctions. Thus, whilst ECOWAS thought it sufficed if Fauré resigned, the AU thought it was also necessary to hold free and fair elections. These contradictory approaches contributed to a political stalemate in Togo, although the envisaged elections were eventually held. ${ }^{68}$ Similarly, the AU and ECOWAS took contradictory decisions regarding

63 Vandeginste S, 'The African Union, constitutionalism and power-sharing', 2.

${ }_{64}$ Vandeginste $\mathrm{S}$, 'The African Union, constitutionalism and power-sharing',14.

65 Adetula VAO, Bereketeab $\mathrm{R}$ and Jaiyebo $\mathrm{O}$, Regional economic communities and peacebuilding in Africa: The experiences of ECOWAS and IGAD, Nordic African Institute, Uppsala, 2016.

${ }_{66}$ Adetula VAO et al, Regional economic communities and peacebuilding in Africa: The experiences of ECOWAS and IGAD, 35 .

67 Adetula VAO et al, Regional economic communities and peacebuilding in Africa, 35.

68 Striebinger K, Coordination between the African Union and the regional economic communities, International Institute for Democracy and Electoral Assistance (IDEA), Stockholm, 2016. 
the conflict in Burkina Faso, following a coup d'état in $2015 .{ }^{69}$ Here, while the AU threatened to impose sanctions, ECOWAS favored foregoing the sanctions.

\section{Conclusion}

The AU's two-pronged institutional framework for handling intra-state conflicts remains work in progress. Member states remain deeply attached to the old-order principles of sovereignty and non-interference, and consequently exceedingly reluctant to embrace and implement the new-order principle of nonindifference. Further, little effort has been put towards implementing continental norms on democracy, governance and human rights. As a result, the AU and the RMs do not speak with one voice. And so it remains the case that they are unable to handle conflicts caused by incumbent regimes retaining power by manipulating the law, the electoral process, or the judicial process.

In these circumstances, it is understandable why the AU-RMs relationship is defined by pragmatism. Two things need to happen, going forward. First, this relationship should be clarified, a process that entails unpacking what its governing principles of subsidiarity, complementarity and comparative advantage mean in practical terms. For example, conflict of interest rules should be established, so that entities or individuals that are conflicted in one way or another do not participate in the management of conflicts. Second, a need arises to harmonise the legal frameworks of the AU and the RMs, so that they can speak with one voice on important questions such as invoking the non-indifference principle and condemning and rejecting unconstitutional changes of government.

69 Desmidt S and Hauck V, 'Conflict management under the APSA', 17. 
